party will proceed to Rostow, at the head of the Sea of Azov, examining a mercury-mine and certain mineral springs, and ultimately reaching Wladikavkaz, on the northern side of the Caucasus mountains. Section $B$ will start, under the guidance of Messrs. Pavlow and Amalitzky, from Moscow to Nijni-Novgorod, across Jurassic and Triassic formations to the Cretaceous rocks of Simbirsk on the Volga. Journeying southwards they will visit asphalt quarries, and by means of steamer and railway they will proceed along the plains of the Volga and the borders of the Kirghiz Steppes to Astrakhan andjWladikavkaz. Section $\mathrm{C}$ will be under the direction of M. Sokolow, and will journey to Kiew on the Dnieper, paying especial attention to the Tertiary and Post-Tertiary deposits. Following the river to Alexandrovsk, the party will ultimately join the two other sections at Wladikavkaz by way of Rostow.

Thus united the whole party will proceed across the mountainous country to Tiflis, under the direction of $M$. Loewinson-Lessing, some few members separating for a while to examine a glacier under the guidance of $\mathrm{M}$. Kolenko. Tertiary, Cretaceous, Jurassic, and metamorphic rocks will be seen. From Tiflis all will proceed to Bakou, on the borders of the Caspian, and thence separating into two portions, they will traverse the mountainous region from east to west, and unite again at Rion. Some may spend a week in the Caucasus, examining the Mamisson glacier; others will have an opportunity of visiting Mount Ararat.

Those who desire to still further continue their fieldstudies among Cretaceous and Jurassic rocks, may take part in a general excursion into the Crimea. They will proceed by steamer from Batoum to Kertch, and eventually, on October 5, there will be a reunion of all the remaining excursionists at Sébastopol. Thus will terminate the great programme of expeditions planned by the geologists of Russia. H. B. W.

\section{THE NEW LABORATORIES AT GUY'S HOSPITAL.}

THE new laboratories which have been erected at Guy's Hospital at the expense of the staff of the medical school, and have entailed an expenditure of about $12,000 l$., were opened by the Prince of Wales on Wednesday in last week. The buildings occupy about one-third of the whole structure which is contemplated, and a further sum of $35,000 \%$. will be required to complete the scheme. The entire building is designed to provide under one roof all the accommodation required by the school in all branches of the medical curriculum. The part of the building now opened contains a well-arranged lecture theatre capable of seating four hundred persons, and beneath it are three dark rooms. The first of these is designed for the reception of the spectrophotometer, polarimeter, and spectroscope, for the use of those engaged in work with them. The other two rooms are intended for galvanometric and photographic work Other parts of the building are occupied by the laboratories and preparation room for physiological and pathological chemistry, a balance room, a calorimeter room, and a gas room. On the top floor the whole of the front of the building is devoted to the laboratory and preparation room for normal and morbid histology. Large classes can be accommodated, and the claims of investigation have received ample consideration.

An address of welcome was read to the Prince of Wales by Mr. Howse, the senior surgeon, and Dr. PyeSmith, senior physician, described the objects of the new building in the following words :-

Yuur Royal Highnesses, my Lords, Ladies, and Gentlemen,I have been asked by my colleagues, the lecturers, demonstrators, NO. I 440 , VOL. 56$]$ and tutors of this school of medicine to state very shortly the use and object of the building in which we stand.

While in every civilised country, except England and the United States, the training of physicians and surgeons is provided for by the Government as part of its duties, here the profession provides for itself and for the public. The schools of medicine in London have formed themselves around the great hospitals, and have only gradually acquired their present importance and repute.

Apart from practical instruction in the wards of the hospital, some knowledge of natural science has always been included in the preparation for this liberal profession. Physicians have always been botanists and chemists, surgeons have always been anatomists; nor need we look far for proofs that the highest attainments in scholarship and mathematics are admirable training for pathology.

During the last sixty years, great has been the development of these preliminary scientific studies, the indispensable foundation of rational, honourable and helpful medicine. We have now not only able lecturers on physics, on chemistry, and on biology, but well-equipped laboratories for each of these subjects, in which our students become practically familiar with scientific facts. We have twice rebuilt or greatly enlarged our museums and laboratories for physiology, for clinical chemistry, for histology, and for the new science of bacteriology. But, again, as our numbers increase and the progress of science goes on, we must pull down our barns and build greater. In medical science, as in a still more important discipline, the Augustinian saying is true, Qui satis dixerit, perditus est. We must go on, if we are not to fall back.

Accordingly, after repeatedly considering various plans for enlarging and remodelling the old museum and laboratories, we determined that none of them were satisfactory; and that we must erect a new building for the important department of physiology; one not comparable to the magnificent palaces which are called "Institutes" at Berlin and Strassburg, but such as may rank with the laboratories of our friendly rivals, St. Bartholomew's, St. Thomas's, and the other schools of London, of Cambridge, and of Edinburgh, fitted for the best possible teaching and the most advanced researches.

This part of the future range of museums and class-rooms is now completed. Immense labour has been bestowed upon it. Similar laboratories in this kingdom, and on the continent, have been visited and studied by our lecturers, and the result is what we have every reason to believe will be sufficient for another fifty years. Two names among many to whom we are deeply indebted demand particular mention-those of the architect, Mr. Woodd, and of Dr. Shaw, the Dean of the Medical School.

It is only right to explain how the necessary funds were raised.

We all know the grievous deficiency of rents which have compelled the Governors of Guy's Hospital to close some of their wards.

We know too, and shall never forget, how you, Sir, came to their help, and how, by your generous and practical aid, the prospects of further crippling of the charity were banished, and replaced by a hope that some day its closed wards might be reopened to the public.

The treasurer of the hospital could not give, and the medical school could never ask for, help from the hospital funds. Every pound given to Guy's Hospital is devoted to the direct relief of the patients. The school does not receive from, but gives to the hospital, with which its prosperity and almost its existence are united.

It is needless to say that the Government does not help medical science as it does on the continent, and our rich men are only beginning to learn to devote their wealth to founding colleges and laboratories and observatories, like those which do honour to our kinsmen across the Atlantic.

Only one resource remained open: we determined to appeal - to ourselves. We made a collection; all giving something as he was able, and with the money thus subscribed this physiological institute was built.

Here physiology will be zealously and efficiently taught, and fresh knowledge will be acquired. The old laboratories, where Sir Wm. Gull, Dr. Pavy, Mr. Golding Bird, and the late Dr. Wooldridge worked, will hand over a good tradition of industry, intelligence, and zeal to their successors, and the benefit will not be only for our students, but for the whole community. 
Such institutes are too few ; for they are not only "lightbringing, but fruit-bearing." They not only form the foundation of scientific and efficient treatment of disease, but are the source whence spring such discoveries as bless the whole world, and crown with the gratitude of nations the names of Jenner, of Simpson, of Pasteur, and of Lister.

One of our kings, sir, zealously helped forward Harvey's immortal work on the movements of the heart and of the blood; another founded the Royal Society, "to search out the secrets of nature by way of experiment."

To you, therefore, as a patron of all that tends to the increase of knowledge and the relief of suffering, we turn and ask your Royal Highness to open this laboratory.

In Harvey's words: $A d$ viliorum animalium inspectionen cum Heraclito apud Aristotelem introire si vultis, accedite, nam neque hic Dii desunt immortales.

The Prince of Wales then declared the building open, and, in the course of a short address, he is reported by the Times to have said:- I understand that the building which I have just declared open is to be used in great part for the study of those sciences which have for their object the observation of the natural laws of life. It was in such observations that your distinguished physician, Sir William Gull, first won renown. Nor is it possible to over-estimate the value of such work in the investigation and treatment of disease. One thing I would venture to impress upon our students-namely, that, in endeavouring to follow in the footsteps of the great and good men whom Guy's delights to honour, they should cultivate that gentle and humane spirit which, not confined to any one school, is the best possession of the medical faculty. I have made careful inquiries, and have every reason to believe that whenever experiments upon animals are performed in this school they are undertaken with the object of promoting advances in medicine and surgery which are likely to be of benefit to suffering humanity, and I have satisfied myself that such experiments are conducted under strict supervision, by highly qualified investigators, and that in practice the only operations performed upon animals which are not in a condition of complete anæsthesia are inoculations and hypodermic injections. Looking back upon the history of this school, one cannot but admire the wonderful powers of observation which enabled such men as Astley Cooper, Bright, Addison, Hodgkin, and Gull, with but slender aid from scientific apparatus, to add so largely to the sum of human knowledge. I need hardly remind you that more than one of these great workers in your profession has had his name perpetuated in connection with the discoveries he made in the wards of Guy's Hospital-discoveries which paved the way for the more enlightened treatment of some of the most frequent, and yet most fatal diseases to which man is subject. That harvest has been gathered, and for the present and future generations it remains, with more exact appliances and more delicate apparatus provided by the sister sciences, to seek on other fields to emulate their illustrious predecessors' example. To this end are needed ampler buildings, specially designed rooms, and complicated mechanical contrivances, all of them involving additional expenditure. Your senior physician has made it clear to all how, relying upon themselves, the staff of the medical school have erected this building. I may be permitted to emphasise the act, to which Dr. Pye-Smith has alluded, that the present building is but an instalment of a more extensive design which is to be completed as soon as funds are forthcoming. I would venture to express a hope that this day may not be long delayed, and that when the building is completed, room will be provided to adequately display the unique collection of wax models which so much interested me when first I visited your museum. The medical staff have expended as much as they safely can, and it is to men of wealth and philanthropic aspirations that we confidently look for further assistance. Let such men once realise that money given for the purposes of medical education directly benefits humanity, and I cannot doubt that that spirit, which has prompted the British people to provide by voluntary effort what in other countries is provided by the State, will prove effective in the present need. On you students of medicineand a medical man, as Dr. Wilks has said, should be a student till he dies-it devolves so to order your life's work that you make the best use of the improved opportunities thus provided, and to take care that the great profession to which you have aspired to belong shall, when you leave it, stand as high in the service and in the affection of the public as it does at the present time.

NO. I 440, vOL. 56$]$

\section{NOTES.}

The Select Committee of the House of Commons appointed to inquire into the administration of the museums of the Science and Art Department has presented an interim report calling attention to the peril of destruction by fire to which the collections at the South Kensington Museum are exposed. After describing the general character of the buildings and their inflammable structure, the Committee conclude their report with the following observation :- " This necessity of providing buildings suitable for the exhibition of the'objects of art and science collected at South Kensington has been long under the consideration of successive Governments. Your Committee regard it as their immediate duty to lay before the House of Commons by means of an interim report their very strong opinion that permanent buildings for the adequate accommodation of the collections at the South Kensington Museum should be proceeded with without delay. They are of opinion that it will be a source of grave discredit to the country if the settlement of this matler, which has been the subject of consideration by Government for many years, and of endless correspondence between the departments concerned, is any longer delayed."

THE Paris correspondent of the Times reports that at Monday's sitting of the Academy of Sciences, M. Moissan communicated the results of his experiments with Prof. Dewar on the liquefaction of fluorine gas. M. Moissan announced that the gas had been liquefied at about $185^{\circ} \mathrm{C}$. below zero. When a current of fluorine gas is passed into an apparatus maintained in the midst of liquid oxygen in tranquil ebullition at a temperature of $-180^{\circ} \mathrm{C}$., liquefaction does not occur. But as soon as that temperature is diminished by exhausting the gas above the liquid oxygen, the liquefaction of the fluorine begins, and a clear yellow and extremely mobile liquid is obtained, which resumes the gaseous state as soon as the temperature rises. This liquid has lost the chemical activity characteristic of fluorine in a state of gas. It no longer attacks glass, silicon, sulphur, or phosphorus. Fluorine at a very low temperature, however, still attacks carburetted hydrogen, and its affinity for hydrogen seems still to exist.

JUST too late for insertion in last week's NATURE we received a cablegram from Prof. A. B. Macallum, Local Secretary for the forthcoming meeting of the British Association at Toronto, asking us to urge members of the Association to apply for Canadian Steamship berths as soon as possible, as the berths still remaining will soon be filled.

SiR ARCHIbAI.D GEIKIE had a hearty reception from geologists in America during his recent visit. The number of Science which has just reached us contains a long article, by Prof. J. F. Kemp, upon the visit of the distinguished director of our geological survey, and it is evident from the account that geologists in America regarded the occasion as one of exceptional interest. Sir Archibald Geikie crossed the Atlantic to open a new course of lectures on geology, founded in connection with the Johns Hopkins University, Baltimore, by Mrs. G. H. Williams. The purpose of the foundation is to support an annual course of lectures in geology, to be given alternately by European and American geologists of distinction; and the fact that Sir Archibald Geikie was chosen to deliver the first course is a high compliment to his learning, as well as a testimony to the breadth of his sympathies. Before he arrived in America, invitations were sent by the Johns Hoplins University to geologists throughout the country, asking them to be present, and to take part in the excursions which had been arranged. In response, fifty or more leading geologists in America accepted. While the lectures were being delivered, short excursions were conducted almost daily to places of 